\title{
Division of Property and Expansion of Participation Rights: Primogeniture and the Rebuttal of Patriarchalism in James Tyrrell and John Locke
}

\author{
Cláudia Elias Duarte ${ }^{1}$
}

\begin{abstract}
The political writings of two English philosophers of the seventeenth century - James Tyrrell and John Locke - devote a considerable part of their thought to the rebuttal of Sir Robert Filmer's patriarchalism. Both defend, as an alternative to an absolute political power based on the paternal right of the king, a government established by the consent of those who are governed; and both assume the topic of primogeniture as central in their counter-arguments against patriarchalism. The present article intends to focus on the anti-patriarchalism arguments devoted to the second topic. Mainly, it tries to identify the reason that may be behind the choice of Sir Robert's critics to deny a right of primogeniture, when that right was in force in their country in the seventeenth century. Departing from the assumption that, then, the exercise of political rights relied of the status of proprietary, then the defense of the end of primogeniture, and the consequent possibility of the division of property by the various members of one family, may open the door to an expansion of the rights of political participation.
\end{abstract}

Keywords: John Locke - Robert Filmer - James Tyrrell - Political Rights - Patriarchalism

\section{Divisão de propriedade e expansão de direitos de participação política: primogenitura e a refutação do patriarcalismo em James Tyrrell e John Locke}

Resumo: Os escritos políticos de dois filósofos Ingleses do século XVII - James Tyrrell e John Locke - dedicam uma parte considerável do seu pensamento à refutação do patriarcalismo de Sir Robert Filmer. Ambos defendem, como uma alternativa a um poder político absoluto baseado no direito paternal do rei, um governo estabelecido pelo consentimento daqueles que são governados; e ambos assumem o tema da primogenitura como central nos seus argumentos contra o patriarcalismo. O presente artigo pretende deter-se nos argumentos anti-patriarcalistas dedicados ao segundo tópico. Tentar-se-á, sobretudo, identificar a razão que poderá estar no facto de os críticos de Sir Robert terem escolhido negar o direito de primogenitura, quando esse direito estava em vigor no seu país no século XVII. Partindo do pressuposto de que, então, o exercício dos direitos políticos assentava-se no estatuto de proprietário, então a defesa do fim da primogenitura, e da consequente possibilidade da divisão de propriedade pelos vários membros da família, poderá abrir a porta para uma expansão dos direitos de participação política.

Palavras-chave: John Locke - Robert Filmer - James Tyrrell - direitos políticos - patriarcalismo

\footnotetext{
${ }^{1}$ Mestre em Filosofia pelo Birkbeck College, University of London. Mestre em Ciência Política e Relações Internacionais pelo Instituto de Estudos Políticos da Universidade Católica Portuguesa. Licenciada em Filosofia pela Faculdade de Letras da Universidade de Lisboa. Investigadora colaboradora do Teoria e História do Direito, Centro de Investigação da Universidade de Lisboa (THD-ULisboa).
} 


\section{Introduction}

The criticism addressed to Filmer's patriarchalism can be of great value for understanding how English political philosophers thought, in the seventeenth century, the extension of the rights of political participation since this issue was, in those days, discussed alongside other issues such as the nature and the limits of political power, and the idea of family.

Considering this, it could be asked why a discussion over the rights of political participation requires a discussion over the idea of family. The answer to this question may reside in the influence that the notion of patriarchalism had in the political thought of the authors of that time. In the seventeenth century, and concretely for Sir Robert Filmer and his critics, the definition of political rights required a previous understanding of the rights of a father. ${ }^{2}$ Filmer, for example in his Essay on the Origin of Government, defends the idea that if an absolute power has its source on a right of paternity, then there is no freedom left for men to choose their ruler through consent. ${ }^{3}$ For Filmer there is a connection between humanity's natural subjection and the divine right of Kings. That royal right was granted by God to Adam, the first father, who conveyed it to his firstborn. This royal right is then inherited by successive generations.

Filmer's critics draw from here a fundamental line of counter-arguments by defending that royal power is inherited de facto, unless it is proved that men are not born subjected. Or in other words, if humanity's natural subjection steams from the fact that men are not born free; then humanity's natural freedom will be derived from the fact that we are born free. If that is the case, if we prove that men are naturally free, then we will be admitting humanity's power to choose its political rulers. This is what Locke's reasoning, the way he settles and formulates the arguments and counter-arguments to put forward, suggests. As the authors says in his First Treatise, if Filmer's thesis - that men are naturally slaves - fails, then governments will have their origin on men's consent. ${ }^{4}$

The same is acknowledged by James Tyrrell who sees in Filmer's writings the denial "[...] that Mankind is naturally endowed and born with Freedom from Subjection, and at liberty to chuse what form of Government it please; and that the Power which any one man hath over others, was at first bestowed according to the discretion of the Multitude" ${ }^{\text {. And }}$ like Locke, Tyrrell also assumes consent as the right alternative to Filmer's patriarchalism. ${ }^{6}$

This is, then, one of the lines of counter-argumentation that was explored by Filmer's critics. This was not, however, the only aspect that was confronted by those critics. An attentive consideration of Filmer's argument may show that the possibility of patriarchalism rests not only on the fact of humanity's natural slavery but also on the possibility to see

\footnotetext{
2 "The familial model that provided the basis for this sort of political thinking [where primitive family is seen as the structural as well as the ideational precursor of the political order] was the traditional or conventional patriarchal household that had long characterized Europe [...]". Cf. SCHOCHET, "Models of Politics and the Place of Women in Locke's Political Thought", p. 132.

3 "If, according to the order of nature, he [Hobbes] had handled paternal government before that by institution [of a commonwealth], there would have been little liberty left in the subjects of the family to consent to institution of government." Cf. FILMER, "Patriarcha”, 1991, p. 185.

${ }^{4}$ Cf. LOCKE, Two Treatises of Government, I $\$ 6$.

5 TYRRELL, Patriarcha Non Monarcha, p. 2.

${ }^{6}$ Cf. TYRRELL, Patriarcha Non Monarcha, p. 5.
} 
Adam's royal right being inherited by the successive generations. This aspect of Sir Robert's thesis inspired another line of counter-argumentation. Considering that the survival of patriarchalism is dependent on its continuity through the centuries, Tyrrell and Locke tried to demonstrate that such power could not pass the test of time for two reasons: firstly, because it would be very hard to know who the right successor of Adam is; and secondly, because that royal power could not be inherited by the older son, and hence it could not be inherited by the successive generations, since history and reason never considered the existence of a right of primogeniture.

Each one of the referred lines of counter-arguments may draw the reader to question the choices made by Filmer's critics. For example, in recent decades, readers have been noticing that the expectation of seeing Filmer's critics denying peremptorily a patriarchal view on political rights does not find support in their writings. ${ }^{7}$ For although John Locke and James Tyrrell affirm the intention of denying the patriarchalist assumptions of their adversary with the idea that mankind is naturally free and equal, the outcome of their arguments falls short when it comes to extend that natural equality and freedom to every human individual. Hence, women, servants, and children are not considered equal; being also defended that they should be subjected to the paternal rule.

The present article intends to focus on a second perplexity that can be drawn from the anti-patriarchalist writings referred previously. That perplexity has specifically to do with the second line of counter-argumentation, that is, with the attack on primogeniture. Mainly, it tries to understand the reason that may be behind the choice of Sir Robert's critics to deny a right of primogeniture, when that right in fact existed in their country in the seventeenth century; and when their historical accounts pointed to the impossibility of the survival of Adam's royal right.

The argument developed will rest upon the assumption that the anti-patriarchalist arguments contain not just a critic to the unlimited extent of paternal power but also a critic to a specific type of family. That critic is opened by the attack on primogeniture. Thus, it will be possible to notice that none of the above cited critics defends an absolute and arbitrary paternal power, like Filmer defended; and it will also be possible to recognize in their arguments the attempt to shape a different kind of family. Moreover, it is upon this intuition that will be defended that although the authors maintain in their political writings some patriarchalist assumptions (and consequently subscribe the denial of political rights to, for example, women), their account of primogeniture, and of property, enables the broadening of political rights. ${ }^{8}$

The political writings of two English philosophers of the seventeenth century James Tyrrell and John Locke - will serve as the primary source to defend that argument since both devote a considerable part of their thought to the rebuttal of Filmer's patriarchalism; both defend, as an alternative to an absolute political power, a government established by the consent of those who are governed being the issue of primogeniture central in their counter-arguments against patriarchalism. The following will address each

\footnotetext{
${ }^{7}$ Cf. SOMMERVILLE, "Family and State”, p. 71; BUTLER, "Early Liberal Roots of Feminism: John Locke and the Attack on Patriarchy"; PATEMAN, The Sexual Contract.

8 About the existence of a close link between property rights and political rights, see ASHCRAFT, "Lockean ideas, poverty, and the development of liberal political thought"; BLUM, "Of women and the land. Legitimizing husbandry"; MACPHERSON, The Theory of Possessive Individualism.
} 
philosopher, paying special attention to the way each understands the limits of the paternal power, the way it is acquired by a particular man, and how the attack on primogeniture seems to allow the expansion of political rights.

\section{James Tyrrell and the expansion of political rights}

Some have questioned the concrete relevance of Sir Robert Filmer's writings in his days. ${ }^{9}$ Despite that fact, it cannot be left unnoticed the way Filmer's ideas draw the readers to address fundamental political issues. In the specific case of the political rights the challenge was formulated almost as a warning:

If Infants and Children be concluded by the Votes of their Parents, this destroys the whole Cause: for if it be allowed that the Acts of Parents bind their Children, then farewell the Doctrine of the natural freedom of Mankind. Where subjection of Children to Parents is natural, there can be no natural freedom. ${ }^{10}$

Tyrrell did not ignore the problem. Probably inspired by the facts of his own times, and keeping present the main assumption that everyone is endowed with natural freedom, he asked how we should consider not only the political rights of children but also those of women and servants. For if "every particular person" has in the state of nature "[...] a Right to preserve himself and to govern his own actions [...]"11, then it could be expected that the political right of electing a governor would be at the reach of everybody.

The way Tyrrell addresses the case of children, however, shows that the mere fact of having a right to self-preservation cannot be understood as a sufficient condition for having, for example, a right to vote. By admitting that a child does not exhibit the signs of mature reasoning that could allow him to "[...] judge what is necessary for his own good and preservation [...]", Tyrrell concludes the necessity of submission "[...] to the parent's judgment in all things conducing to that end"12. Furthermore, since a political government is for " $[\ldots]$ the preservation and security of every Subject $[\ldots]$ ", and "[...] for the common good of mankind in general" 13 , then its institution requires a previous judgment of what private and common good is. The ability to reason and specifically the ability to identify what is needed for one's preservation and good seem to be, therefore, necessary conditions to have political rights.

Children were excluded from the equation. Still, it would be reasonable to expect that all particular adults, or all those who reveal the capacity to judge the means to achieve their own good, could have access to political rights. Tyrrell chose, however, not to go that far. By attempting a historical interpretation of the beginning of governments, he admits that "[...] it is likely that Commonwealths were first instituted by Fathers of Families, having

\footnotetext{
${ }^{9}$ Cf. ZUCKERT, “An Introduction to Locke's First Treatise”; PANGLE, The Spirit of Modern Republicanism; TARLTON, “A Rope of Sand: Interpreting Locke's First Treatise of Government”.

10 TYRRELL, "Patriarcha”, p. 270.

11 TYRRELL, "Patriarcha", p. 57.

12 TYRRELL, "Patriarcha", p. 38.

13 TYRRELL, "Patriarcha", p. 38.
} 
Wives, Children, and Slaves under their Domestick Government" ${ }^{\prime 14}$. It is not accurate to say, therefore, that civil government had its origin in the consent of the people "[...] since the Fathers of Families, or Freemen at their own dispose, were really and indeed all the People that needed to have Votes"15.

Women, whose judgment had just been considered relevant for determining all the things that can assure the good and preservation of children ${ }^{16}$, are now excluded from the right to vote. The reason for this seems to be rooted, in part, on the natural inequality between the sexes. The law of nature, and also the law of God, confirms that the woman is "the weaker wessel", while the man is "[...] the stronger, stouter, and commonly the wiser creature, to whose care and courage she must owe the greatest part of her provision and protection" ${ }^{17}$. Marriage is a contract regulated by the law of nature and consequently based on natural assumptions; it establishes the subjection of women to men on the basis that he is "[...] commonly stronger both in body and mind than the Woman"18.

Having been coquetted, and having given her consent to submit to a man's power, the woman becomes dependent on his political decisions. For "Civil Government does not owe his Original to the consent of the People, since Women, as being concluded by their Husbands, and being commonly unfit for civil business, [...] had no reason to have Votes in the Institution of the Government" ${ }^{19}$. The exclusion of women from political choices has to do, therefore, not only with the fact that they are under the power of a man, but also with the natural fact of their inability to deal with public affairs.

The case of servants also poses obstacles to the defense of a broader extension of the rights of political participation. Servants, but also adult sons, by remaining in their master's, or father's, house, may give their tacit consent to obey him in family issues. For Tyrrell this is how things actually happen since he does not conceive why it should not be this way. For it is rational that a father, "[...] if he be a wise and good man, and hath carried himself as a good Father or Master ought toward them [...]" should retain his authority, legitimized by the tacit consent of those servants and children who agree to obey him " $[\ldots]$ in all things tending to the common good of the Family"20. This obedience is towards the representative power of the father, who may "[...] vote for them, and represent them in the choice of a Governour" ${ }^{\prime 2}$.

The reasoning implicit in the description of the situation of servants seems to presuppose an important aspect: those who have political rights are supposed to represent the interests of a family. That does not mean, however, that the exercise of political rights is exclusively associated with the role of the father. This is a conclusion that cannot be drawn because the author admits that " [...] whoever is a Master of a distinct Family, or a single man at his own dispose, and not a Servant, shall have a Vote in the Government" 22 . Hence a single man can also have a vote, as long as he is not a servant, that is, as long as he is "at his own

\footnotetext{
14 TYRRELL, "Patriarcha", p. 36.

15 TYRRELL, "Patriarcha", p. 42.

${ }^{16}$ Cf. TYRRELL, "Patriarcha", p. 38.

17 TYRRELL, "Patriarcha", p. 10.

18 TYRRELL, "Patriarcha", p. 53.

19 TYRRELL, "Patriarcha", p. 42.

20 TYRRELL, "Patriarcha", p. 20.

${ }^{21}$ TYRRELL, "Patriarcha", p. 40.

22 TYRRELL, "Patriarcha", p. 20.
} 
dispose". But despite these considerations, it should be noted that if the acquisition of political rights seems to be at the reach of emancipated sons; and if those who have those rights may be supposed to represent the interests of a family; then marriage seems to play an important role for is one condition of emancipation and it establishes the power of the father. The idea of marriage is therefore essential to understand how someone becomes an independent head of a family, being also crucial to understanding the nature and extent of the power attached to that position.

As it has been suggested, this is a representative power since "Women, Children, and Servants, who had had no Votes in its Institution, might be supposed as represented by their Husbands, Fathers, and Masters"23. Marriage must be able, therefore, to formalize the authority of the husband over his wife; as well as the paternal authority over children. More concretely, the marriage contract must be able to allow the father to achieve one of the main conditions associated with the exercise of political power, that is, a power to represent his family in all matters. And marriage seems indeed to guarantee that condition for "the Authority of the Husband over the Wife, commences from that Contract we call Marriage"24; as it is also "(...) evident, that this Power of Fathers over their children, can only take place in the state of Wedlock; so as to Children got out of Marriage, it is uncertain who is their Father (...). So that the Right of the Father over his Child, commences by vertue of the Marriage" 25 .

The marriage contract, by establishing who the head of the family is, helps insuring his independence. For "all these Fathers of Families being alike free and independent, can in the state of Nature claim no Superiority over each other" ${ }^{26}$. More specifically, a marriage contract establishes the independence of the son from his father's authority. This is asserted by Tyrrell against Filmer and is grounded on the idea that " $[. .$.$] neither Paternal Authority$ nor Filial Subjection is absolute or perpetual in the state of Nature [...]"27. Bearing in mind the temporal limits of the paternal power, Tyrrell denies the exclusion of "[...] all Sons from having Votes whilst their Fathers are alive, although they are married, and have separated into distinct Families"28. The same idea is repeated shortly after, but then adding another condition, that is, the requisite of having property: "[...] these Sons so making divers Families, and having Estates distinct from their Fathers, ought likewise to have Votes in the Government" ${ }^{\prime 2}$.

The fact of having property does not seem to be a mere sign of the son's independence. In fact, an emancipated son is distinguished from a subdued son by the fact that the later does not possess "[...] any property in Goods or Land [...]" 30 . Plus, those children who have no property have "[...] no reason to have Votes in the Institution of the Government" 31 . In a certain way the appropriation of goods and land is a mark in the appropriation of the son's independence and power.

\footnotetext{
23 TYRRELL, "Patriarcha”, p. 53.

${ }^{24}$ TYRRELL, "Patriarcha", p. 53.

25 TYRRELL, "Patriarcha", p. 10.

26 TYRRELL, "Patriarcha", p. 44.

27 TYRRELL, "Patriarcha", p. 39.

28 TYRRELL, "Patriarcha", p. 39.

${ }^{29}$ TYRRELL, "Patriarcha", p. 40.

30 TYRRELL, "Patriarcha", p. 42.

31 TYRRELL, "Patriarcha", p. 42.
} 
One major question arises from this argument: does not Tyrrell assume that every human being is recognizably independent from the power of others, and therefore in some instances equal, regardless of whether or not they are the head of a family? The answer is yes. Regardless gender, position or estate, everybody is endowed with a natural right to selfpreservation. For instance, a wife should not submit her will entirely to her husband's

$[\ldots]$ as not to reserve to her self the faculty of a rational woman, as not to judge when her Husband would evidently destroy her self or Children, or absolutely ruine the Family, when he was not in a capacity to govern himself. So likewise if the Husband command her to do any thing against her Conscience, or the Laws of Nature, she is not obliged to obey him..$^{32}$

As for the son, and when self-preservation is at stake, he may be considered equal to his father since he has a "[...] Right to defend himself in what belongs to him from the unjust violence of his Father"; where by doing so he doesn't "[...] act as his Superiour; but in this case as his Equal, as he is indeed in all the Rights of Nature, considered only as a Man; Such as are a Right to live, and to preserve himself, and to use all lawful means for that end"? ${ }^{33}$ Hence, "[...] this Right of Children in defending their Lives, and not being obliged to give them up at their Fathers pleasure $[\ldots]]^{\prime 34}$.

The same reasoning is applied to the case of the servants because for Tyrrell " [...] even a Slave (much more a Servant hired upon certain Conditions) in the state of Nature, where he hath no civil power to whom to appeal for Justice, hath as much Right as a Son or Child of the Family, to defend his life, or what belongs to him, against the unjust violence or rage of his Master" ${ }^{35}$. The reason for such is common for the previous cases of women and children: to the right of human self-preservation, and particularly to its supposed exercise, it is attached the condition of being capable of rational thinking. For a woman, by reserving to herself the faculty of being rational, can challenge her husband when hers or her children's life are at stake. A son can disobey his father when his commands "[...] appear impossible or extravagant, such as a Father may give when he is in a fit of drunkenness, madness, or sudden rage, which is all one with madness" 36 ; being that act of defense a product of the ability of the son to judge, in the state of nature,

[...] the reasonableness or lawfulness of their Parents Commands, and of the condition they are in when they gave them: for otherwise a Child ought to be of his Fathers Religion, though it were Idolatry, if he commanded it; or were obliged to break any of the Laws of Nature, if this Obedience were absolute" (TYRRELL, 1991, p. 15). And of servants it is said that "[...] no man can be supposed so void of common sense (unless an absolute Fool, and then he is not capable of making any Bargain) to yield himself so absolutely up to

\footnotetext{
32 From where Tyrrell concludes: "I am not of the opinion of some, who will have the Husband, in the state of Nature, to be endued with an absolute power of life and death over his Wife". TYRRELL, "Patriarcha", p. 55. 33 TYRRELL, "Patriarcha", p. 16.

34 TYRRELL, "Patriarcha", p. 23.

35 TYRRELL, "Patriarcha", p. 51.

36 TYRRELL, "Patriarcha", p. 14.
} 
another's disposal, as to renounce all hopes of safety or satisfaction in this life, or of future happiness in that to come. ${ }^{37}$

Since women, children and servants are not eligible for having political rights, it might be reasonable to assume that the fact of being naturally independent from the arbitrary power of another is not considered a sufficient condition in order to acquire those political rights. Moreover, it can be noticed that Tyrrell refers himself to those who have political rights as "freemen at their own disposal", specifically distinguishing these freemen from servants. ${ }^{38}$ But what does Tyrrell mean by "freemen"?

Firstly, by freemen Tyrrell may be referring the masters of the distinct families. In this case we have the notion of "political independence" as being in the hands of the "Heads of separate Families"; and so a man who has a vote in the institution of the government is said to be a "Master of a distinct Family". ${ }^{39}$ The independence recognized in a head of a family is, in the case of the exercise of political representation, attached to his role of defending the private interests of his own family, considered separate and distinct from all the others. And here it seems to be implicit the idea that a freeman is endowed with natural freedom but also with a capacity to decide and to act according with his own decisions. To be able to deal with public affairs or to engage in civil business, may be considered a sign of freedom. Going further, insofar as a father represents his own family, his representative power does not reach other families. The decisions of the father of the family bind his own family; those decisions do not bind other families. This might be, then, how that independence of the heads of the families is reflected upon the political realm.

Secondly, those freemen may also be understood as single men for Tyrrell assumes the possibility "[...] that Governments may have been at first begun by Fathers of Families and other Freemen" ${ }^{40}$. He also assumes that "[...] whoever is a Master of a distinct Family, or a single man at his own dispose, and not a Servant, shall have a Vote in the Government $[\ldots]^{\prime 41}$. From here it might be possible to defend that to represent a family isn't a necessary condition for having political rights.

What is, then, necessary to be considered fit to deal with public affairs? From all those conditions that were implicit in the denial of political rights of women, children and servants - to have a right to self-preservation, to be able to reason and determine what is good and how to attain it, to be able to deal with "civil business", to represent a family's interest, to be free and master of his own life, to have property in goods and land - which may be considered not only sufficient but also necessary conditions to acquire political rights?

From what was exposed so far, it may be possible to affirm that the specific conditions that allow a man to have political rights seem to be those that are common to a father of a family and any other single man. Those conditions have to do with natural freedom but also with the ability to deal with civil business, and to have property. As it was shown before, the right to self-preservation, the ability to determine what is good and the

\footnotetext{
${ }^{37}$ TYRRELL, "Patriarcha", p. 51.

${ }^{38}$ Cf. TYRRELL, "Patriarcha", p. 42.

${ }^{39}$ Cf. TYRRELL, "Patriarcha", p. 20.

40 TYRRELL, "Patriarcha", p. 39.

${ }^{41}$ TYRRELL, "Patriarcha", p. 20.
} 
means to achieve it, and the fact of representing a family are all necessary conditions though they do not seem to be sufficient.

Despite the supposed exiguity of the range of political rights, Tyrrell's arguments allow the broadening, at least in theory, of those rights. For if those are the specific conditions to be entitled to vote, then Tyrrell may be opening an opportunity for women to acquire political rights. Firstly, because the subjection of women depends upon the fact that men are stronger in body and mind; and, for Tyrrell, when "[...] that ceases the subjection will likewise of course cease". Secondly because the author admits that

if a Husband be a foolish or a careless man, and either cannot or will not govern his Family and Estate, the Wife may and does, and oftentimes him into the Bargain: Nor does any one finde fault with her for so doing, since somebody must govern the Concerns of the Family; and if the man either cannot or will not, who hath more Right or Interest to do it, than her, who hath an equal share in the happiness and well-being of her Family and Children? ${ }^{42}$

More, the limits imposed to the paternal power also extend themselves to a possible power acquired by a right of primogeniture. For Tyrrell does not see, in the Sacred Scriptures nor in the law of nature, an antecedent or a reason to defend that "[...] Adam's eldest Son was by the Right of Eldership to be Lord over his Brethren, without their Election or Consent, when their Father died" 43 . The end of the right of primogeniture, then, allows each son to be considered free even after his father's death.

By undermining the right of primogeniture, Tyrrell seems to be subscribing to an argument, common also to Locke, which enables the introduction of changes in the way a family is understood. More specifically, this argument, by allowing the emancipation of, at least, all the brothers, is opening the possibility of multiplying the number of men who may exhibit the conditions to be endowed with political rights. The following part will try to isolate the arguments that John Locke addressed specifically against the right of primogeniture defended by Filmer, trying also to assess the possible consequences of such attack, namely the changes in the idea of family and the broadening of political rights.

\section{John Locke and the appropriation of the right of political participation}

As it was possible to notice in the work of the authors previously referred to, the counter-arguments addressed to Filmer's patriarchalism are frequently marked by a biblical exegesis. It is also possible to notice, however, that the Sacred Scriptures are not used by those authors solely because they are a vehicle of God's word. The Bible was considered by Tyrrell, as far as the issue of primogeniture is concerned, especially as a historical account of the initial times of mankind.

This intuition may also find support in John Locke's Two Treatises. The biblical events described by Filmer in order to defend the thesis of the continuity of the patriarchal royal

42 TYRRELL, "Patriarcha", p. 53-54.

43 TYRRELL, "Patriarcha", p. 26. 
power are understood as pieces of history ${ }^{44}$; his patriarchalism is said to rest upon his very own version of the "Scripture History" 45 . Most probably in order to accommodate his argumentative scheme to that of Filmer's, Locke seems to be drawn to build one of his lines of offensive against patriarchalism by confronting his adversary's interpretation of the history of mankind. That line of counter-argumentation, then, required of the Two Treatises a historical approach to the development of political societies. For this reason we are able to see, alongside the famous argument presented in the beginning of the Second Treatise, another argument, based not on the existence of an abstract natural state but on the concrete existence of a "golden age" 46 which had place "in the first Ages of the World" 47

Therefore, and in conformity with the assumption that "[...] History gives us but a very little account of Men, that lived together in the State of Nature" ${ }^{38}$, the philosopher, guided by beliefs and suggestions ${ }^{49}$, goes on attempting a description of the beginning of human societies. He notices that as far as the historical records show, Commonwealths were in the beginning "[...] under the Government and Administration of one Man"50. Specifically, and considering the conditions in which men lived in those first times, that governor might have been the father of the family:

$[\ldots]$ where a Family was numerous enough to subsist by it self, and continued entire together, without mixing with others, where it often happens where there is much Land and few people, the Government commonly began in the Father. ${ }^{51}$

The existence of this paternal rule seems to owe, however, much of its existence to the conditions in which men lived in those first times. One of those conditions is the preeminence that a father had in his family. Plus, his devoted care to the family and all its members made it easy for the governed to be under the power of "[...] such nursing Fathers tender and carefull of the publick weale" ${ }^{\prime 2}$. Children, for example, were by education accustomed to the "Rule of one man", their father, exercised with "[...] Care and Skill, with Affection and Love to those under it $[\ldots]$ " 53 . For this reason the paternal rule seemed to be enough to " $[. .$.$] procure and preserve to Men all the Political Happiness they sought for, in$ Society" ${ }^{\prime \prime}$.

Once established the paternal preeminence, and the privileges annexed to it, it would have to exist a way of ensuring the continuity of the paternal rule. That continuity was guaranteed by the right of primogeniture. The existence of such right is implicit when the philosopher refers the possibility of a son, probably the eldest, to succeed after his father's

\footnotetext{
${ }^{44}$ Cf. LOCKE, Two Treatises, I, \$143.

${ }^{45}$ LOCKE, Two Treatises, I, \$154. See also LOCKE, Two Treatises, I, S\$57, 113.

${ }^{46}$ LOCKE, Two Treatises, II, $\$ 111$.

${ }^{47}$ LOCKE, Two Treatises, II, $\$ 74$.

48 LOCKE, Two Treatises, II, \$101.

${ }^{49}$ The tone that introduces Locke's descriptions of the first times of mankind seems to be hesitant. Cf. LOCKE, Two Treatises, II, \$\$105, 106, 107.

${ }^{50}$ LOCKE, Two Treatises, II, $\$ 106$.This thesis is reaffirmed in LOCKE, Two Treatises, II, $\$ 107$.

${ }^{51}$ LOCKE, Two Treatises, II, \$105.

${ }^{52}$ LOCKE, Two Treatises, II, $\$ 110$.

${ }^{53}$ LOCKE, Two Treatises, II, \$107.

${ }^{54}$ LOCKE, Two Treatises, II, \$107.
} 
death. ${ }^{55}$ Also, the assumption that primogeniture existed allows Locke to conceive a type of family that "[...] by degrees grew up into a Commonwealth $[\ldots]$ ". 56. For this to happen it is fundamental to guarantee that the fatherly authority may continue on to the elder Son, to whom everyone tacitly submits.

It is, therefore, defended that the right of primogeniture would enable families " $[\ldots]$ to be numerous enough to subsist by it self, and continue entire together, without mixing with others $[\ldots]^{\prime, 57}$. The paternal rule is then applied to this extended family. And it grows with the family's own growth. The limits that may be imposed to the growth of the paternal rule may reside, hence, in those obstacles that inhibit the family from becoming extended.

One of those obstacles is the end of the right of primogeniture. Perhaps it would be more accurate to say that for Locke, in fact, primogeniture never existed as a right. And that for two main reasons. Firstly, because the philosopher describes the facts of those first times as being purely circumstantial. Therefore, the fact, observed in the first times, that the older son inherited his father's power might be a consequence of the circumstances in which people lived in the beginning. In a similar way, as it was shown before, the paternal rule was a product of those same circumstances. Moreover, both powers (of the father and of the older son) are said to end when circumstances change. Hence, if the submission to the paternal power is tacitly accepted, that is because those who submit " $[. .$.$] had neither felt the$ Oppression of Tyrannical Dominion, nor did the Fashion of the Age, nor their Possessions, or [the] way of living (which afforded little matter for Covetousness or Ambition) give them any reason to apprehend or provide against it" ${ }^{38}$. The "Frame of Government" under which they were was "[...] best suited to their present State and Condition [...]" for when life is poor and simple, desires are confined "[...] within the narrow bounds of each man's small property $[. . .]^{159}$ and so few laws are needed in order to solve small controversies.

Secondly, it can be stated that Locke never considered primogeniture as a right because such right cannot be found neither in the law of nature nor in the biblical history. Since all children have, by the law of nature, a right to inherit their father's property ${ }^{60}$, they might be able to enjoy it and "[...] no one could pretend to the whole Inheritance, or any Sovereignty supposed to accompany it, since a Right of Inheritance gave every one the rest, as well as any one, a Title to share in the Goods of his Father" ${ }^{\prime \prime 1}$. Also, biblical events show that the primogeniture was not considered in the first times of mankind. The dominion which Sir Robert attributes to the older son after his father's death is not, Locke corrects, the "[...] Right of the Heir, but only a Greater Portion of Goods [...]" ${ }^{62}$; Isaac, who is recognized to have received a greatest part of his father's property, " [...] by being Heir, he had no Right to be Lord over his Brethren"'33; the Law stated, then, that "[...] the Priviledge of

\footnotetext{
55 "But when either the Father died, and left his next Heir, for want of Age, Wisdom, Courage, or any other Qualities, less fit for Rule”. Cf. LOCKE, Two Treatises, II, \$105.

${ }^{56}$ LOCKE, Two Treatises, II, \$110.

${ }^{57}$ LOCKE, Two Treatises, II, \$105.

${ }^{58}$ LOCKE, Two Treatises, II, $\$ 107$. See also Locke, Two Treatises, II, $\$ 75$.

${ }^{59}$ LOCKE, Two Treatises, II, $\$ 107$.

${ }^{60}$ This right to inheritance is founded in the right "[...] a Man has to subsist and enjoy the conveniences of Life $[\ldots]$... Cf. LOCKE, Two Treatises, I, $\$ 97$.

${ }^{61}$ LOCKE, Two Treatises, I, $₫ 91$.

${ }^{62}$ LOCKE, Two Treatises, I, $\$ 114$.

${ }^{63}$ LOCKE, Two Treatises, I, \$114.
} 
Birth-right was nothing but a double Portion [...]" of the father's goods and it didn't give “[...] Rule of Empire, Paternal or Kingly Authority, to any one over his Brethren" ${ }^{64}$.

Historical events show, in fact, that in those days there were many kings. This fact leads Locke to defend that "[...] Kings deriv'd their Power from some other Original than Fatherhood, since some of these had Power over more than their own Posterity, and 'tis Demonstration, they could not be all Heirs to Adam" "65. Plus, the stories of Abraham and $\mathrm{Jacob}$ are referred to in order to show the inexistence of a right of primogeniture. Concretely, Abraham, who was supposed to be a king "as Heir to Adam", and Lot, "[...] who was of the same Family [...]", lived "[...] as Friends and Equals, and when their Herdsmen could not agree, there was no pretence of Jurisdiction or Superiority between them [...]"66. Jacob, and his brother Esau, "[...] lived with the Friendship and Equality of Brethren, neither Lord, neither Slave to his Brother, but independent each of other, were both heads of their distinct Families [...]"67.

The description of biblical times, and the focus given by Locke to the equality between sons and subsequent independence, seem to have implicit a correction to his first interpretation of the first times. Unless we assume that the referred biblical times were not exactly the first times of mankind. Still, the equality among siblings, and the possibility given for each son to constitute his own family appear as conditions to assure the limits of the paternal rule.

Moreover, the equality that Locke seems to have in mind is rooted in freedom. That becomes evident when the philosopher assumes that both the father and the son can become free, being henceforward considered equals. ${ }^{68}$ More specifically, the power "[...] that Parents have over their Children, arises from that Duty which is incumbent on them, to take care of their Off-spring, during the imperfect state of Childhood" ${ }^{69}$. But that parental jurisdiction lasts only while the child doesn't have "[...] Understanding of his own to direct his Will"70. Hence, the son becomes free when he "[...] comes to the Estate that made his Father a Freman $[\ldots]]^{\prime 71}$. Also, one of the concrete facts that may express the freedom to which the son is entitled (or the denial of the perpetual jurisdiction of the parents) is marriage since he is authorized to "[...] leave Father and Mother and cleave to his Wife" "72. To this temporal limit of the parental power, Locke adds other limits, namely those that have to do with property and, consequently, with political participation. For the power of the father " $[\ldots]$ extends not to

\footnotetext{
${ }^{64}$ LOCKE, Two Treatises, I, $\$ 115$. Adding to this, even if it is asserted that the older son can inherit his entire father's property, still that wouldn't give him a right of sovereignty in his family. The explanation given by Locke is the following: the power that the father has over his children cannot be transmitted to the older son since that power has its original in the "Act of Begetting"; and "Power founded on Begetting, he only can have that Begets". Cf. LOCKE, Two Treatises, I, \$96. This argument, however, seems to be in conflict with the idea that paternal power may not be founded on begetting. Cf. LOCKE, Two Treatises, II, $\$ 65$.

${ }^{65}$ LOCKE, Two Treatises, I, $\$ 149$.

${ }^{66}$ LOCKE, Two Treatises, I, $\$ 135$.

${ }^{67}$ LOCKE, Two Treatises, I, $\$ 118$.

68 “[...] Father and Son are equally free as much as Tutor and Pupil after Nonage; equally Subjects of the same Law together, without any Dominion left in the Father over the Life, Liberty or Estate of his Son [...]”. Cf. LOCKE, Two Treatises, II, \59.

${ }^{69}$ LOCKE, Two Treatises, II, $\$ 58$.

${ }^{70}$ LOCKE, Two Treatises, II, \58.

${ }^{71}$ LOCKE, Two Treatises, II, \58.

${ }^{72}$ LOCKE, Two Treatises, II, $\$ 65$.
} 
the Lives or Goods [of their children], which either their own industry, or anothers bounty has made theirs"

The case of property is, thus, particularly important to assess the concrete political rights that the son may acquire when he becomes free. The specific way by which Locke understands the process of appropriation can enlighten the issue here in discussion. For if a son is free when he is able to understand and guide his own will ${ }^{74}$, it can also be noticed that that freedom is expressed in the possibility of appropriating and maintaining goods. Since "[...] every Man has a Property in his own Person", then "the Labour of his Body, and the Work of his Hands, we may say, are properly his" ${ }^{\text {"75 }}$. The independence gained by the son is not, therefore, given in advance. It is required the development of the ability to reasoning; but also that independence seems to express itself, and in a certain way seems to be built, by the act of appropriation. Plus, the concrete results of the process of appropriation, that is, the possessions that the independent son may acquire by his labour, can be seen as the concrete bound between him and the govern to which he is subjected because "[...] every Man, when he, at first, incorporates himself into a Commonwealth, he, by his uniting himself thereunto, annexed also, and submits to the Community those Possessions, which he has, or shall acquire $[\ldots]^{\prime, 76}$.

The obedience due to a government is, therefore, closely linked to the possession of land for " $[. .$.$] there being always annexed to the Enjoyment of Land, a Submission to the$ Government of the Country [...]"'77. And, consequently, with the enjoyment of land, and with the independence that it enhances, the son becomes a subject of a government.

\section{Conclusion}

Filmer's patriarchalism produced, as it was shown before, a number of counterarguments against tyranny. Tyrrell and Locke were not, however, denying a plain and simple absolute power. They were, in fact, committed to the rebuttal of an absolute power founded on a right of paternity. The patriarchal aspect of the power to delegitimize is affirmed and reaffirmed by the philosophers, at every step of their counter-argumentation. Because of that, the patriarchal power that Filmer defended as belonging to a king was confronted with the paternal power that belongs to every particular father of a family. That ended up being the power that is said to pose limits to the power of a king.

At the same time, the paternal power, the one that belongs to each father, was subjected to a redefinition of its limits. The absolute power that was due to a father became an absolute duty of both parents to ensure the preservation of their children. Still, it is the father who is thought to be empowered with a right to represent the family in common matters.

On the other hand, it was possible to see how it seems to be included, in the counterarguments addressed to Filmer, a possible way to attribute political rights to a larger number

\footnotetext{
${ }^{73}$ LOCKE, Two Treatises, II, $\$ 65$.

74 " $[\ldots]$ there be a time when a Child comes to be as free from subjection to the Will and Command of his Father, as the Father himself is free from the subjection to the Will of any body else [...]". Cf. LOCKE, Two Treatises, II, $\$ 66$.

${ }^{75}$ LOCKE, Two Treatises, II, $\$ 27$.

${ }^{76}$ LOCKE, Two Treatises, II, $\$ 120$.

${ }^{77}$ LOCKE, Two Treatises, II, $\$ 73$.
} 
of people. The attack on primogeniture, and the consequent emancipation of siblings, tears the family apart. Extended families may, then, be replaced by what is known today as nuclear families. Going further, it was possible to notice that the attack on primogeniture is closely linked to the defense of human labor as a means of appropriation. Plus, the end of the right of primogeniture seems to promote the end of large dominions of land. And that for two reasons: firstly because the equal division of the father's property, after his death, may promote the equal division of large portions of land by his children; secondly, because a particular young man cannot appropriate himself, solely by his own efforts, of a large portion of land or other goods. If, as it was intended to defend in this article, this link between the exercise of political rights and the status of proprietary exists, then the end of primogeniture and the consequent possibility of the division of property may open the door to the expansion of rights of political participation.

\section{References}

ASHCRAFT, Richard. "Lockean ideas, poverty, and the development of liberal political thought”. In: Early Modern Conceptions of Property. London: Routledge, 1996.

BLUM, Carol. "Of women and the land. Legitimizing husbandry". In: Early Modern Conceptions of Property. London: Routledge, 1996.

BUTLER, Melissa. "Early Liberal Roots of Feminism: John Locke and the Attack on Patriarchy”. In: American Political Science Review, 72 (1978).

FILMER, Robert. "Patriarcha". In: Patriarcha and Other Writings. Cambridge: Cambridge University Press, 1991.

FILMER, Robert. "The Original of Government". In: Patriarcha and Other Writings. Cambridge: Cambridge University Press, 1991.

LOCKE, John. Two Treatises of Government. Cambridge: Cambridge University Press, 1967.

MACPHERSON, C. B. The Theory of Possessive Individualism: Hobbes to Locke. Oxford: Oxford University Press, 1962.

PANGLE, Thomas. The Spirit of Modern Republicanism: the moral vision of the American founders and the philosophy of Locke. Chicago: The University of Chicago Press, 1998.

PATEMAN, Carol. The Sexual Contract. Stanford: Stanford University Press, 1998.

SCHOCHET, G. "Models of Politics and the Place of Women in Locke's Political Thought". In: Feminist Interpretations of John Locke. Pennsylvania: The Pennsylvania State University Press, 2007.

SOMMERVILLE, Johann. 1992. "Family and State". In: Thomas Hobbes: political ideas in bistorical context. New York: The Macmillan Press, 1992. 
TARLTON, Charles.“A Rope of Sand: Interpreting Locke’s First Treatise of Government”. In: John Locke Critical Assessments. London and New York: Rutledge, 1991.

TYRRELL, James. Patriarcha Non Monarcha. London: Richard Janeway, 1681.

ZUCKERT, Michael. “An Introduction to Locke's First Treatise”. In: Jobn Locke Critical Assessments. London and New York: Routledge, vol. III, 1991. 